\title{
Subtropical seed-bank of a Bay of Plenty dairy farm
}

C.C. BELL

AgResearch Grasslands, Private Bag I 1008, Palmerston ,North

\begin{abstract}
An examination of the grass seed-bank on a Bay of Plenty dairy farm in October 1994 found seed numbers of all grass species were greatest in the top 0-50 $\mathrm{mm}$ of the soil profile and declined steeply at two lower sampling depths (5 1-150 mm, 151 $250 \mathrm{~mm}) . \mathrm{C}_{4}$ grass species comprised $58 \%$ of the total viable seed in the upper sampling layer and greater than $80 \%$ in the other two horizons. Panicum dichotomiflorum was the dominant $\mathrm{C}_{4}$ grass, especially at the lowest sampling depth where it comprised over $90 \%$ of the $\mathrm{C}_{4}$ seeds and $78 \%$ of the total seeds found. Previous management was also an important influence on both the total seed loading and its distribution within the soil profile. Paddocks cultivated within the last 4 years had more total viable seeds at all depths and more Panicum dichotomiflorum seed at the deeper sampling depths than paddocks not cultivated within the last 4 years. The almost total absence of perennial ryegrass (Lolium perenne) seed indicates that it has a very short residual life in the seedbank. Therefore, if ryegrass plants are not maintained by vegetative propagation ryegrassbased pastures are susceptible to invasion from species that have a long residence time in the seedbank. These results also show that seed-bank surveys provide a method for assessing the potential changes in botanical composition of pastures and the geographical distribution of species such as subtropical grasses that is independent of the growing conditions at the time of sampling.
\end{abstract}

Keywords: $\mathrm{C}_{\mathbf{4}}$ grasses, Panicum dichotomiflorum, seed-bank, subtropical grasses

\section{Introduction}

$\mathrm{C}_{4}$ grasses, especially annual species, have been cited as a problem in dairy farms in the northern half of the North Island of New Zealand (Moloney 1990). They have been implicated in reduced milk output because of their lower herbage quality compared with $C_{3}$ grasses and by their tendency to form dense mats that suppress ryegrass growth in the late autumn and early winter.
Because the only source for the continued presence of many of the $C_{4}$ species is the seed-bank, it is important to quantify seed-bank reserve if the potential for changes in the size of the $C_{4}$ grass component in pastures is to be estimated and the consequences for forage supply and milk production quantified. This paper describes the seed-bank in pastures with different management backgrounds on a Bay of Plenty dairy farm.

\section{Methods}

The farm selected for sampling was located about $5 \mathrm{~km}$ west of Edgecumbe on the Edgecumbe-Matata road. Twelve paddocks were sampled; 5 had been cultivated and returned to pasture within the last 4 years and 7 had been in pasture for greater than 4 years. Twenty-four 18 $\mathrm{mm}$ diameter soil cores were taken from each paddock. All cores were divided into 3 depths: 0-50 mm, 51-150 $\mathrm{mm}$ and 151-250 $\mathrm{mm}$ and bulked on a per paddock basis to give a total of 36 samples. The farm was sampled on 19 October 1994. Soil cores were analysed by the Palmerston North Seed Testing Station, The soil cores were placed in fine mesh bags and washed under running water to remove fine soil particles. The samples were then air dried and sieved into several particle sizes and each separation hand-sorted for $\mathrm{C}_{4}$ and $\mathrm{C}_{3}$ grasses. Viable seeds were counted, viable seeds being defined as tilled seeds firm to the touch. These data were $\log$ transformed and analysed using the generalised linear model procedure of SAS (SAS Institute 1987).

\section{Results}

The $\mathbf{C}_{3}$ grass species found in the samples were Poa species, Gfyceria species, Lolium species, Agrostis capillaris, Holcus lanatus. $\mathrm{C}_{4}$ grass species found were Panicum dichotomiflorum, Digitaria sanguinalis, Eleusine indica, Paspalum dilatatum, Axonopus affinis and Setaria species. $C_{3}$ grasses comprised $32 \%$ of the total grass seed-bank, Poa species constituting $96 \%$ of the $\mathrm{C}_{3}$ grass seed. Panicum dichotomiflorum made up $84 \%$ of the $\mathrm{C}_{4}$ grass species found in the samples. Digitaria sanguinalis was present in a few samples in high numbers and was the second most common $C_{4}$ found (results not shown). Most grass seeds were located in the $0-50 \mathrm{~mm}$ layer with fewer seeds at the 
deeper sampling depths (Table 1). Cultivated paddocks had nearly twice the number of total grass seeds and a more even spread of seeds throughout the soil profile than non-cultivated paddocks. These trends were similar for total $\mathrm{C}_{4}$ grasses and the $\mathrm{C}_{4}$ grass Panicum dichotomiflorum. $\mathrm{C}_{4}$ grass species comprised $58 \%$ of the total viable seed in the upper sampling layer and greater than $80 \%$ in the other two horizons. Panicum dichotomiflorum seed increased from $48 \%$ at the $0-50$ $\mathrm{mm}$ sampling depth to $78 \%$ of the total grass seeds ( $90 \%$ of the $\mathbf{C}_{\mathbf{4}}$ seeds) at the deepest sampling depth.

Table1 Seeds $/ \mathrm{m}^{2}$ contained within the soil profile for cultivated and non-cultivated paddocks sampled to 3 depths $\quad(1=0$ $50 \mathrm{~mm}, 2=51-150 \mathrm{~mm}, 3=151-250 \mathrm{~mm}) . * *$ indicates that the cultivation by depth interaction is significant at $\mathrm{P}<0.01$.

\begin{tabular}{lccccrrr}
\hline \multirow{2}{*}{ Depth } & $\begin{array}{c}\text { Panicum } \\
\text { Cult. }\end{array}$ & seeds & \multicolumn{2}{c}{$\boldsymbol{C}_{4}$ grass seeds } & \multicolumn{2}{c}{ Total grass seeds } \\
\hline 1 & 5240 & 5708 & 6975 & 7053 & 14344 & 9650 \\
2 & 5338 & 2971 & 6140 & 3157 & 7532 & 3977 \\
3 & 2947 & 327 & 3177 & 327 & 3733 & 444 \\
\hline
\end{tabular}

\section{Discussion}

Panicum dichotomiflorum, the main $\mathbf{C}_{\mathbf{4}}$ grass found at this site, was first recorded in New Zealand in c. 1945, having originated from North America (Healy 1945). It was not a sown species and its rate of spread is determined by how quickly seed is dispersed to new sites. Consequently, in the time available since its introduction it is unlikely that Panicum dichotomiflorum has established in all the locations where it is potentially able to survive. In North America, Echinochloa crusgalli has been shown to adapt to cooler climates (Potvin \& Strain 1985) with plants grown in cooler environmental conditions producing fewer but heavier seeds with superior germination percentages to those grown in warmer conditions (Potvin 1991). Given the recent introduction to New Zealand of $\mathrm{C}_{4}$ species it is unlikely that they have had time to genetically adapt and extend their range to some of the cooler parts of New Zealand; however, they may well have the potential to do so.

Once present at a site, Panicum dichotomiflorum is likely to be very persistent as it has a very long seed longevity, one estimate suggesting that buried seed would decline to $1 \%$ germination after 300 years (Burnside et al. 1981). At this site large quantities of seed have remained viable at depth for at least 4 years since being turned under by cultivation. Continuous cropping has previously been shown to encourage the survival of $\mathrm{C}_{4}$ grasses (Allo 1959; Franklin 1980) but the results presented here, from a farm where cropping is limited to a 2 year maximum under crop before being resown to pasture, indicate that even short periods of cultivation have the potential to increase the proportion of $\mathrm{C}_{4}$ species in pastures.

Although seed-bank surveys can show only the potential regenerative power of a pasture and do not necessarily reflect the above-ground herbage composition at any single point in time, these results show how they partly overcome the limitations of herbage surveys for detecting changes in species composition. To describe species composition from botanical surveys requires (I) sampling at several times of the year in order to account for the different seasonal growth patterns of the species present, and (2) sampling between years in order to account for inter-annual variations in climate that markedly influence species composition. In contrast, a single seed-bank survey, taken at any time of the year, can detect all hard-seeded species and a twice yearly sampling (late summer-early autumn and late winter-early spring) will detect species without dormancy. This technique provides a valuable tool for deciding which paddocks to manage strategically to reduce the impacts of $\mathrm{C}_{4}$ grasses on the farming system.

The spread of $\mathbf{C}_{\mathbf{4}}$ grasses in New Zealand may be related to the warmer temperatures recorded over the last 50 years (Salinger et al. 1993). Associated climatic factors such as more frequent drought may also play a part in $\mathrm{C}_{4}$ responsiveness to global warming. Matthews (197 1) suggested that Panicum dichotomiflorum was developing into a worse weed problem than Echinochloa crus-galli because of its ability to survive under drier conditions, However, without further evidence it would be premature to ascribe the perceived increase in $C_{4}$ species in the northern regions of New Zealand to global warming. As already indicated; even in the absence of any change in climate, $\mathrm{C}_{4}$ grasses will probably continue to spread in New Zealand as they extend out from their point of introduction in warmer areas and as they adapt to cooler temperatures. This may also interact with land use changes. For example, cropping practices have already been found to have an important influence and there have probably been profound effects on pasture composition through the dramatic $47 \%$ decline the last 10 years in the number of sheep in the Northern Region (The New Zealand Meat Producer 1995).

The results presented here highlight the fragile nature of perennial ryegrass-based pastures. Ryegrass seed has no dormancy or after-ripening mechanisms (Thompson \& Grime 1979), and most ryegrass seed germinates before the end of May (Hume \& Barker 1991), which explains the low level of ryegrass seed found in these 
samples taken in October. Therefore, ryegrass seed does not build up in the seed-bank, leaving ryegrass pastures primarily dependent on tillering for persistence and spread (Langer 1973). If pasture damage such as pugging occurs over the winter-spring period then under favourable climatic conditions, gaps in the pasture will be filled by species already present in the seed-bank. Judging by the results of this and other surveys (Cox 1977), these species will be annual $\mathrm{C}_{3}$ and $\mathrm{C}_{4}$ grasses and broad-leaf weeds.

Several strategies for reducing $\mathrm{C}_{4}$ grass species in dairy pastures have been suggested by Bell \& Keene (this proceedings). However, with seed of such longevity it is unlikely that Panicum dichotomiflorum will be easy to eradicate, as once it has established a significant seed pool it will be present for decades and replenish its seed pool when the right growing conditions occur.

\section{ACKNOWLEDGEMENTS}

Mike and Kay Watkins for allowing their property to be sampled and Barry Keene of Bay Milk Products Ltd for help in selecting the farm. Mr N. Grbavac of Palmerston North Seed Testing Station for advice on processing seed samples. Drs Harry Clark and Paul Newton for helpful comments of this manuscript.

\section{REFERENCES}

Allo, A.V. 19.59. Weed problems of the Bay of Plenty. Proceedings of the New Zealand Weed Control Conference 12: 17-23.

Burnside, O.C.; Fenster, C.R.; Evetts, L.L.; Mumm, R.F. 1981. Germination of exhumed weed seed in Nebraska. Weed science 29: 577-586.
Cox, T.I. 1977. Weeds in spring seedbeds. Proceedings of the New Zealand Weed Control Conference 30: $1-7$.

Franklin, S.J. 1980. Weed control in Asparagus. Proceedings of seminar on Asparagus: 37-47, Advisory Services Division, MAF, Hamilton.

Healy, A.J. 1946. Contributions to a knowledge of the naturalised flora of New Zealand. No 1. Transactions of the Royal Society of New Zealand 75: 399-404.

Hume, D.E.; Barker, D.J. 1991. Natural reseeding of five grass species in summer dry hill country. Proceedings of the New Zealand Grassland Association 53: 97-104.

Langer, R.H.M. 1973. Pastures and Pasture Plants. A.H. \& A.W. Reed, Wellington, New Zealand.

Matthews, L.J. 1971. Warm-zone annual grasses. Proceedings of the New Zealand Weed and Pest Control Conference 24: 85-89.

Moloney, S. 1990. 'Huge change' in pastures; ryegrass losing battle. Dairy exporter, August: 22.

Potvin, C. 199 1. Temperature-induced variation in reproductive success: field and control experiments with the $\mathrm{C}_{4}$ grass Echinochloa crus-galli. Canadian journal of botany 69: 1577-l 582.

Potvin, C.; Strain, B.R. 1985. Photosynthetic response to growth temperature and $\mathrm{CO}_{2}$ enrichment in two species of $\mathrm{C}_{4}$ grasses. Canadian journal of botany 63: $483-487$.

SAS Institute 1987. SAS/STAT Guide for personal computers, Version 6 Edition. SAS Institute, Cary, North Carolina.

The New Zealand Meat Producer 1995. The business of New Zealand meat Vol. 23 No. 2.

Thompson, K.; Grime, J.P. 1979. Seasonal variation in the seed banks of herbaceous species in ten contrasting habits. Journal of ecology 67: 893-92 1 . 